\title{
Quantitative assessment of environmental impacts at the urban scale: the ecological footprint of a university campus
}

\author{
C. Genta ${ }^{1} \cdot$ S. Favaro ${ }^{2} \cdot$ G. Sonetti ${ }^{1}$ (D) $\cdot$ G. V. Fracastoro ${ }^{3} \cdot$ P. Lombardi ${ }^{1}$
}

Received: 20 July 2020 / Accepted: 23 July 2021 / Published online: 17 August 2021

(c) The Author(s) 2021

\begin{abstract}
This paper explores the consumption-based ecological footprint method and its application aiming at a quantitative assessment of the sustainability of a university campus. The goal is to inform the planning decision-making process and evaluate the socio-technical solutions implemented in local urban settings for reducing energy consumption, decreasing environmental impacts and improving the quality of life of the campus' inhabitants. The case study taken for the analysis is the Politecnico di Torino, a Higher Education Institution (HEI) located in Northern Italy counting around 33,000 enrolled students in 2016. Data were collected from departments and administrative units of the Politecnico di Torino to identify the pressure exerted by the campus activities on the ecosystem during a reference year (2016). The study identified six main categories of consumption that were associated with their ecological footprint, i.e. the amount of land needed to produce the required resources and to absorb the generated waste, including $\mathrm{CO}_{2}$ emissions. Total footprint resulted in 6,200 gha: about half of the total city area, meaning that the campus would need a 310 times larger area to be self-sufficient. Normalizing this result with the number of students yields 0.19 gha/student. Transports had the highest share, with $49.4 \%$ out of the total campus impact, whereas energy covered $40.1 \%$. Food, waste, land use and water counted, respectively, for $5.7 \%, 3.7 \%, 0.7 \%$ and $0.5 \%$. This study presents the most comprehensive analysis to date of the environmental impact associated with an Italian HEI. This methodology and its implementation for the specific case of HEIs contribute to gain a better understanding of the overall impact of a university campus, as well as to create thresholds for comparative analysis, decision-making tools and policymaking to reduce the ecological footprint of the educational sector.
\end{abstract}

Keywords Emission analysis · Higher education - Sustainability assessment - Decisionmaking $\cdot$ Carbon footprint $\cdot$ Ecological footprint $\cdot$ Environmental awareness

G. Sonetti

giulia.sonetti@polito.it

1 Interuniversity Department of Regional and Urban Studies and Planning, Politecnico di Torino and Università di Torino, Turin, Italy

2 Department of Architecture and Design, Politecnico di Torino, Turin, Italy

3 Department of Energy, Politecnico di Torino, Turin, Italy 


$\begin{array}{ll}\text { Abbreviations } \\ \text { EF } & \text { Ecological Footprint } \\ \text { GFN } & \text { Global Footprint Network } \\ \text { gha } & \text { Global Hectares } \\ \text { HEI } & \text { Higher Education Institution } \\ \text { MPT } & \text { Masterplan Team } \\ \text { PoliTO } & \text { Politecnico di Torino } \\ \text { RUS } & \text { Rete delle Università per lo Sviluppo Sostenibile (Sustainable Development } \\ & \text { University Network) } \\ \text { SDG } & \text { Sustainable Development Goal }\end{array}$

\section{Introduction}

In the last few years, debates about the climate crisis increase in importance and media resonance, involving different types of activists and experts around the world: 2019 was also the year of student climate strikes, led by the movement Fridays for Future which involved millions of students around the world. The crucial role of the human beings in the climate crisis has been acknowledged also in the scientific arena, beginning from Paul Crutzen (Steffen et al., 2011) who introduced the term "Anthropocene" to represent the human responsibility in affecting the current ecological unbalance (Steffen et al., 2011).

Other scientific reports, like the ones by the Intergovernmental Panel on Climate Change (IPCC), recognize the priority need to reduce global energy, materials and food demand about the Earth biocapacity (IPCC, 2018). An increasing number of scholars acknowledge the crucial role of personal behaviours in addition to technological improvements; those changes in behaviour and lifestyle could include the different areas of individual consumption (food, transport choices, energy use and goods consumption patterns) (Castellani et al., 2019; Sala \& Castellani, 2019; Vanham et al., 2019) impacting heavily on the current social, economic and environmental crisis. Urbanization, economic growth and energy consumption raise environmental degradation, while trade acts more in the long term, decreasing environmental quality (Nathaniel, 2020a). The findings of an exploratory study by Nathaniel (Nathaniel, 2020b) suggest also that biocapacity, economic growth and urbanization increase the $\mathrm{EF}$ (even if not everywhere in the world in the same way and at the same speed), while human capital exerts a reverse influence.

The integrated nature of the current crisis is reflected in the framework of Sustainable Development Goals (SDGs), where 17 goals adopted by the United Nations (UN) in 2015 (UN, 2015) are set to guide future development including the crucial role of the built environment. (Baranzelli et al., 2019; Colglazier, 2015).

Higher Education Institutions (HEIs) have critical roles in implementing SDGs and their mission-driven approaches for reducing their direct impacts and provoking a change at urban scale (Leal Filho et al., 2018; Patrizia Lombardi \& Sonetti, 2017). Many scholars describe the new role of University exactly as moving from a teaching and research placebased hub, to a driving force for the knowledge economy of regions, leveraging on a learning community about climate change threats, awareness and solutions (Genta et al., 2019; Mulder et al., 2015; Tejedor et al., 2019).

Evaluating the environmental impact of HEI and in general the contribution to foster sustainable development principles "practising what we preach", became a key issue (Sonetti et al., 2016, 2020). In the mare magnum of sustainability assessment methods for HEIs 
(Brandon \& Lombardi, 2011; Caeiro et al., 2013), it is hard to find holistic, comprehensive, balanced criteria, able to encourage good practices without creating confusion or conflicts in the evaluation process. In line with Disterheft et al., (2014, 2016) and Shriberg (2002), a useful evaluation process should go beyond the "what", by also integrating "why" and "how", investigating choices, missions, visions and incentives.

The Ecological Footprint (EF) is a methodology widely used for assessing the environmental impact of human activities, for its power to represent with a unique number how much of the biosphere's regenerative capacity humans are consuming and compare this amount with how much is still available (Goldfinger et al., 2014). EF method is now quite widespread and has been used globally at different levels of detail, from a single product to the global scale (Kitzes et al., 2009), as well as in different types of organizations, both private, public and NGOs, but still rarely in urban settlements or university campuses (Baabou et al., 2017; Collins et al., 2018). The way trade, economic growth and energy consumption affect EF in different national or regional contexts has been explored by several scholars worldwide ( Omojolaibi \& Nathaniel, 2020; Udemba, 2020a, b, c).

Being aware of the limitations deriving from the selection of a specific object of study (a university campus) and a specific scope (its EF), this paper presents the results of a sustainability evaluation exercise aiming at fostering sustainable development awareness in the local community and improving the sustainability performance of the university campus itself (Leal Filho et al., 2018; Lombardi \& Sonetti, 2017).

In the following paragraph, the EF methodology is presented in its theoretical framework (par. 1.1) and its concrete application to a university campus, the Politecnico di Torino (PoliTO) case study (par. 2). Results (par. 3) show the total PoliTO's Ecological Footprint (EF), obtained summing up the EF of the different consumption categories, namely Energy (Electricity, Heating), Water, Mobility (Commuting students, Commuting staff, Work trips), Land use, Waste (Recycled waste, Unsorted waste), Food (Canteen, Bar). Acknowledging the ambiguity of the EF indicators regarding the mobility impact, the analysis encompasses two extreme scenarios (one more "eco-friendly" and one less "ecofriendly") and an intermediate situation considered as the most reliable. Discussion and conclusions (par. 4) illustrate the final results compared to other previous studies. Finally, limitations of the study, its implications in the campus management and further development are presented.

\subsection{The ecological footprint}

The EF methodology adopted by the Global Footprint Network (GFN) since 2003 is based on Rees and Wackernagel works (Rees \& Wackernagel, 1996; Wackernagel \& Rees, 1997). It reflects the land required to deliver our daily consumption and it encompasses six types of footprints, namely cropland for the provision of plant-based food; grazing land for animal products; forest for timber; fishing grounds for fish products; carbon uptake land to neutralize $\mathrm{CO}_{2}$ emissions; and built-up land for shelter and infrastructures (Borucke et al., 2013). Each of these groups takes its specific biocapacity, conveyed in "global hectares" (gha). The global hectare is a quantity based on the average productivity of the earth's land areas in one year; this value can change in years and is related to the paradox of an increasing biocapacity of human-altered ecosystems (Galli et al., 2016).

The methodology has received many critiques in the last years (Galli et al., 2016; Giampietro \& Saltelli, 2014; Goldfinger et al., 2014). Main limitations identified by the literature refer to (i) the not-homogeneous uncertainty degrees in the different impact 
calculation methodologies; (ii) the definition of biocapacity; (iii) the uneasy process of boundaries definitions; (iv) the underlying simplifications and (v) the scarce reliability of a normalized indicator for the overall performance (Goldfinger et al., 2014; Munier, 2011). Nevertheless, all the previous are paid back by the significant advantage of providing a recognizable figure of the environmental impact and, at the same time, a clear starting point for further policies developments. EF makes it possible to obtain a snapshot of current situations readable by non-experts and comparable to current studies about human impact on our planet (Steffen et al., 2015; Vanham et al., 2019). Despite being a complex indicator to calculate, EF is still an easier and "tangible" way to transfer a final impact to a wider audience (T. Wiedmann \& Barrett, 2010), especially for environmental education purposes (Collins et al., 2018).

While industries, administrations and organizational institutions focus most on sustainability management practices (Schaltegger \& Wagner, 2006; Schaltegger et al., 2006; Schuetze \& Chelleri, 2015), university policymakers have generally failed to adopt consumption-based measures on the subnational levels (K. Turner et al., 2007). This could be partly due to the lack of consistent and accountable impact info at the local level of carbon footprint emissions per sector (Ivanova et al., 2017), although university campuses, as a consistent landowner in a city, may have a significant role to play (Agdas et al., 2015; Chung \& Rhee, 2014; Escobedo et al., 2014; Ferrer-Balas et al., 2009). Moreover, an EF analysis is in line with the recommendation to 'practice what it is preached' by professors, unfolding the most significant impacts in a university community and fostering awareness among staff and students (Cortese, 2003; Gottlieb et al., 2012; Sonetti et al., 2016).

Despite this potential, assessing and recording impacts via the EF method are still not much widespread among higher education institutions (Lozano, 2010; Velazquez et al., 2006). Sustainability reporting is an overly complicated endeavour, often managed by nonacademics and therefore the "tick-the-box" exercise remains without consequences to enable environmental performances to both be compared with other institutions and tracked in the same institution through time (Lozano et al., 2014; Ramos et al., 2015).

Universities adopting the EF method generally aim at i) incorporating sustainability into their core business (T. O. Wiedmann et al., 2009); ii) submitting a sustainability report (Townsend \& Barrett, 2015); iii) using it as a teaching tool with students (Collins et al., 2018; Li et al., 2008); iv) paving the road to new policies (Deakin et al., 2002; Townsend \& Barrett, 2015) and v) elaborating new scenarios (Conway et al., 2008a, b). According to many scholars (Chambers et al., 2014; Klein-Banai \& Theis, 2013; Lambrechts \& Van Liedekerke, 2014; Larsen et al., 2013), EF proved to be a sound foundation for reporting, acknowledging uniformity, comparability and communicability of the sustainability outcomes in universities (Larsen et al., 2013; Nunes et al., 2013; Ozawa-Meida et al., 2013). However, the literature about EF in Higher Education Institutions (HEIs) lacks specific analysis regarding carbon (Baboulet \& Lenzen, 2010; Klein-Banai \& Theis, 2011; Thurston \& Eckelman, 2012) and ecological (Conway, et al., 2008a, b; Klein-Banai \& Theis, 2011; Venetoulis, 2006; Wood et al., 2010) footprints and no cases about the Italian context have been found.

This paper tries to fill this gap by presenting the first Italian University campus impact assessment obtained via the EF method and covering all elements of the university's activities. The calculation was done in the framework of the Sustainable Path programme of Politecnico di Torino (PoliTO), which represented the case study and whose results have been used to support the refurbishment, environmental policymaking and master planning of the campus. 


\section{Methodology}

The PoliTO campus is sprawled in different buildings around the city of Turin, in Northern Italy. The main site hosts the engineering campus, and it is located in Corso Duca Degli Abruzzi. The historical and most representative site of PoliTO is the Valentino Castle, a 17th-century royal residence, which is the main teaching campus for Architecture, Planning and Design. The newest campus is the "Cittadella of Design and Sustainable Mobility", next to the manufacturing plant of Mirafiori, a former automotive factory.

PoliTO started its Sustainable Path programme in 2015 by creating a "Green Team". This administrative office identified five target areas for data collection and sustainability interventions: energy and building, mobility and transport, food, water and waste, urban outreach and procurement. For most of them, no accountable calculation of $\mathrm{EF}$ has ever been made, except for the energy consumption and production which is monitored by the living laboratory, a special real-time data monitoring system available inside the university. Therefore, the method used to calculate the EF of the PoliTO campus was based on the literature review of both scientific papers and reports by European and American universities, as well as by Italian municipalities and regions. The EF componential method was adopted with a bottom-up approach gathering local-level data (physical flows of materials and energy, input-output tables, etc.) (Baabou et al., 2017), to obtain quantitative support for future decisions, both from the environmental impacts reduction and the strategic planning of the campus.

Five methodological steps were necessary to develop the analysis:

- Definition of reference terms

- Definition of consumption components and flows

- Data collection

- Consumption analysis for each consumption category

- Ecological Footprint evaluation

As a reference for the collection of data was chosen the 2016 year. In 2016, PoliTO counted more than 33,000 students and around 1700 employees, including 900 professors and researchers. The physical boundaries of PoliTO premises were adopted for the analysis of main consumption patterns. However, while a university campus has precise physical boundaries, the related activities to be taken into account when measuring the environmental impact of a HEIs (e.g. transport, food production, waste disposal) do not always take place within these boundaries, making it difficult to identify them.

In the calculation of the $\mathrm{EF}$, the following processes have been considered: both research and teaching activities and subsidiary actions that describe how students, professors and employees move, consume food and interact with other people. Successively, flows of energy and materials that enter and exit the campus system boundary each day were identified. These are related to six categories and related components as shown in Table 1.

Each category was successively connected to the EF land types impacted. The consequent analysis framework is shown in Fig. 1 and reports the "flows" that were measured to quantify the EF.

Every flow (from consumption to land type) was developed separately, aggregated for every consumption category and in the final phase in the total EF. Every flow was 
Table 1 Components selected for the calculation of the EF of the Politecnico di Torino Campus

\begin{tabular}{ll}
\hline 1 & $\begin{array}{c}\text { Direct energy use (heat from district heating, } \\
\text { natural gas and electricity) } \\
\text { Water (tap water and rainwater) } \\
3\end{array}$ \\
$\begin{array}{c}\text { Mobility (daily commuting of students and } \\
\text { employees, work trips out of the campus) } \\
\text { Infrastructure (buildings, roads and parking lots) } \\
5\end{array}$ & Waste (recycled and non-recycled waste) \\
6 & Food (food consumed in canteens and cafés) \\
\hline
\end{tabular}

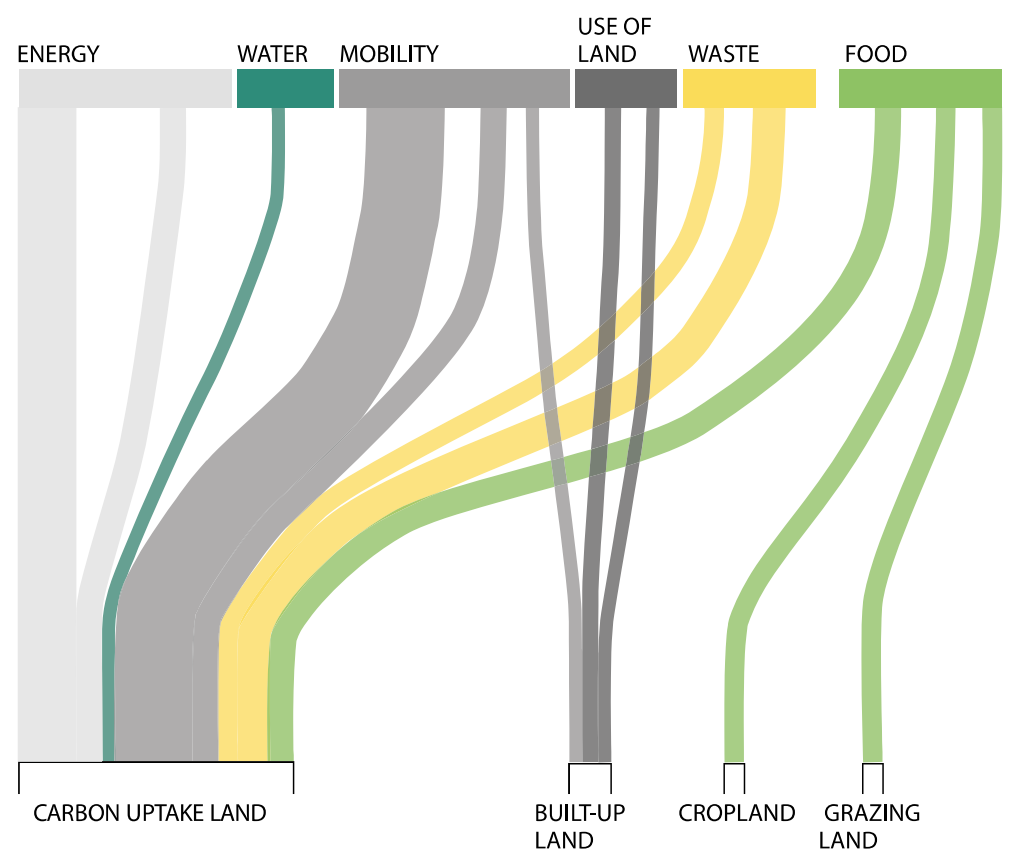

Fig. 1 The types of land corresponding to the different EF categories

quantified through the adoption of two main equations. The first one is about the definition of the productive footprint related to the depletion of natural resources which affects built-up land, cropland and grazing land:

$$
\text { Productive footprint }[\text { ha }]=\text { consumption }[t] \div \operatorname{productivity}\left[\frac{t}{h a}\right]
$$

The second one is the carbon footprint $(\mathrm{CF})$ related to carbon dioxide emissions expressed as the amount of productive land area required to uptake them (Weidmann \& Minx, 2007). It refers to the impacts on the carbon uptake land.

$$
\text { Carbon footprint }[\text { ha }]=\text { emission }[t C o 2] * \text { absorption }\left[\frac{h a}{t C O 2}\right]
$$

Most of the considered actions consume energy and, for this reason, have a corresponding CF. The total CF indicator can be compared to similar cases across different contexts. 
In Table 2, methods and tools used for data collection are reported for each consumption category.

In the next sub-sections, a short description of methodological steps followed to evaluate emissions and consumptions of every consumption category is reported.

\subsection{Energy}

For the energy consumption category, the study considered the use of electricity, natural gas and heat in the main campuses. Electricity at Politecnico is used for several activities, among all: lighting, air conditioning, computers and other appliance for teaching and research. The total consumption in 2016 was around $16 \mathrm{GWh}$, mainly concentrated during the period of occupancy (from 9 am to $6 \mathrm{pm}$ ) and monitored by the living laboratory. However, a practically constant load of $1 \mathrm{MW}$, even at night and during holidays, was recorded, due to night-time safety-lighting, along with servers and IT equipment necessarily turned on $24 \mathrm{~h}$ a day.

The electricity consumed by Politecnico may be considered $100 \%$ "green" because it is purchased through the "Garanzia di Origine (Source Warranty)" (GO) certificate. In the Italian policy framework, this qualifies the renewable origin of the energy provided. Therefore, for the EF calculation, emissions in the case of energy from renewable sources should be zero. However, the electricity withdrawn from the Italian network was not considered as "carbon-free", taking the GO certificate just like virtual merit. To reduce withdrawals from the electricity grid, a new $600 \mathrm{~kW}$ photovoltaic system was installed in spring 2017, which has produced in its first year about $750 \mathrm{MWh}$ and $800 \mathrm{MWh}$ in 2019 , i.e. $4.3 \%$ of the total electricity consumption of Politecnico. However, this share of really carbon-free electricity production was not considered in the calculation, since it was not present in 2016. Thermal energy is purchased by the Turin district heating network for the main campus site, while the remaining buildings are heated by natural gas boilers. EF of energy category is composed of the "carbon uptake land", that is the forested area necessary to absorb the $\mathrm{CO}_{2}$ emissions associated with this consumption. Once the energy-related $\mathrm{CO}_{2}$ emissions were determined according to the emission factors from the Istituto Superiore per la Protezione e la Ricerca Ambientale (ISPRA) and IREN (the local company of district heating) (Table 3), the carbon uptake land was calculated by using the mean global forest absorption factor of $3.59 \mathrm{tCO}_{2}$ /ha per year (Lin et al., 2016). The final result, expressed in gha, was obtained by using the equivalence factor of the forested land of 1,28 gha/ha (Global Footprint Network, 2016).

Table 2 Methodologies adopted for data collection

\begin{tabular}{lll}
\hline $\begin{array}{l}\text { Consumption } \\
\text { category }\end{array}$ & Data source & Administrative offices involved \\
\hline $\begin{array}{lll}\text { Energy } \\
\text { Water }\end{array}$ & Consumption Data & Living laboratory/ Energy manager office \\
Mobility & Consumption Data & Living laboratory \\
Waste & A survey from the Mobility manager & $\begin{array}{c}\text { Mobility manager office/travel refund } \\
\text { administrative office }\end{array}$ \\
Food & Interviews and direct observation & Waste manager/facility management office \\
\hline
\end{tabular}


Table 3 PoliTO energy consumption in 2016 and related $\mathrm{CO}_{2}$ emissions

\begin{tabular}{lllll}
\hline Energy Vector & Energy Consumption & $\mathrm{CO}_{2}$ emission factor & $\begin{array}{l}\text { Data source for } \\
\text { emission factors }\end{array}$ & $\mathrm{CO}_{2}$ emission [t] \\
\hline Electricity & $15,670 \mathrm{MWh}$ & $325 \mathrm{~kg} / \mathrm{MWh}$ & ISPRA (2015) & 5077 \\
Heat & $12,355 \mathrm{MWh}$ & $120 \mathrm{~kg} / \mathrm{MWh}$ & IREN & 1492 \\
Natural Gas & $230,264 \mathrm{~m}^{3}$ & $1.9 \mathrm{~kg} / \mathrm{St} \mathrm{m}$ & ISPRA (2015) & 437 \\
Total & & & & 6997 \\
\hline
\end{tabular}

\subsection{Water}

As for the water consumption category, emissions related to treatment, transport and water distribution procedures were considered. Though water is a natural resource used to produce goods and services, it is not a material generated by a "biologically productive" area, nor a waste absorbed by it. Therefore, EF from water use is not calculated in terms of yield, as for the harvests from forests or fields. For this reason, the EF methodology does not provide the calculation of the footprint directly associated with the consumption of water. On the contrary, the footprint associated with the water distribution system is measured and then translated into gha.

In 2016, water consumption at PoliTO was about 250,000 $\mathrm{m}^{3}$. This consumption is linked to the needs for drinking, sanitary, cleaning and irrigation services, along with the cooling process of machines and other purposes related to research and educational activities. The water volume taken from the city aqueduct was multiplied by a conversion factor of $0.37 \mathrm{~kg}$ of $\mathrm{CO}_{2} / \mathrm{m}^{3}$ (Global Footprint Network, 2016) which considers $\mathrm{CO}_{2}$ emissions related to water distribution and treatment.

\subsection{Transport}

The EF linked to transports aims at representing the forested area needed to absorb the $\mathrm{CO}_{2}$ emissions linked to the work trips and the home-university commuting of PoliTO's teaching, student and administrative staff.

Every day, almost 30,000 persons (students, professors and employees) reach offices and classrooms of the different PoliTO's campus sites using different means of transport. The daily commuting of students has flexible characteristics in terms of transport choices. Several scholars analysed the mobility attitude of students communities, identifying some factors that can influence them such as demographic factors, socio-economic factors, the built environment and environmental knowledge attitudes (Romanowska et al., 2019; Soltani et al., 2019).

Therefore, data about commuting were retrieved from a survey conducted by the Mobility manager office during fall 2016, asking PoliTO users about their travel habits. The survey received 1586 responses (1232 students, 206 employees and 148 researchers and professors). This sample was cleaned from all unreliable questionnaires or with missing information. The final sample consisted of 1,202 students, 196 employees and 144 researchers and professors. The sample represented about $5 \%$ of the PoliTO population, too small to give an exact picture of the home-university commuting, but sufficient to give the order of magnitude of the environmental impacts linked to this aspect. The survey 
consisted of five questions: the city of provenience (i); the ZIP code (ii); the home-work distance (iii); the means of transport (iv); the ordinary campus of work/study (v). Respondents usually selected multiple means of transport, since travelling choice often depends on the concurring weather conditions. Therefore, two extreme scenarios were analysed: one including the "most eco-friendly" choice, with the increased use of the bike/foot option and another considering the "least eco-friendly" one. The total travelled km for commuting were evaluated for students and employees by multiplying the number of users, the average distance (round trip), the working days in a year (150 days for students, 180 for employees). Finally, $\mathrm{CO}_{2}$ emissions have been calculated for each type of travel choice by multiplying the travelled $\mathrm{km}$ and the $\mathrm{CO}_{2}$ emission factor expressed in $\mathrm{kg}$ of $\mathrm{CO}_{2}$ per $\mathrm{km}$ per passenger (World Resource institute et al., 2014) (Table 4). The study did not take into consideration the internal transfers of students and staff between the different university premises and the travels by non-city-resident students during holiday seasons.

A database from the administrative office for travel refunds was used for the calculation of the EF due to the national and international work trips by PoliTO staff. The database accounted for 9157 national and international journeys done during 2016 (2914 flights, 4237 train journeys, 2006 car travels) and contained the destination of each trip and the type of service for which a refund has been requested: air travel, fuel, taxi, local buses, train, etc. To calculate the distances covered, Turin was conventionally considered the starting point. Afterwards, the distance was multiplied by the emissions factor related to the specific means of transport (Table 3) (World Resource institute et al., 2014).

\subsection{Soil consumption}

The soil consumption category represents the surface occupied by PoliTO's buildings and other impervious surfaces, such as roads and parking areas. Data were collected through the Archibus platform (https://archibus.com), an integrated workplace management system used by PoliTo for the management of its premises. The platform is integrated bi-directionally with construction info and computer-aided design (CAD) maps and provides information on the PoliTO's campuses and related functions. In some cases, data were verified with direct measurements on technical drawings by the authors. It is important to stress that the EF connected to soil consumption does not directly correspond to the actual imprint of buildings and roads, but it is multiplied by the built-up land coefficient about its productivity index. Subsequently, the area of built land was transformed into global hectares via a corresponding equivalence factor of 2.56 gha/ha (Global Footprint Network, 2016). The result is 45 gha, mostly from the engineering campus in Corso Duca Degli Abruzzi (35 gha).

\subsection{Waste}

The EF linked to the waste produced by PoliTO represents the forested area necessary to absorb the $\mathrm{CO}_{2}$ emissions produced by combustion, degradation and disposal of waste generated by the various activities of PoliTO. No monitoring has ever been conducted aimed at quantifying the amount of waste produced by the university and the percentage of recovered material via closed-loop activities (upcycling of remaining laboratory materials, hardware, furniture, etc.). For this reason, the calculation for waste's EF derived from an inspection carried out by the authors along with the main sites of the campus in collaboration with the facility management office and the cleaning service. The fieldwork for data 


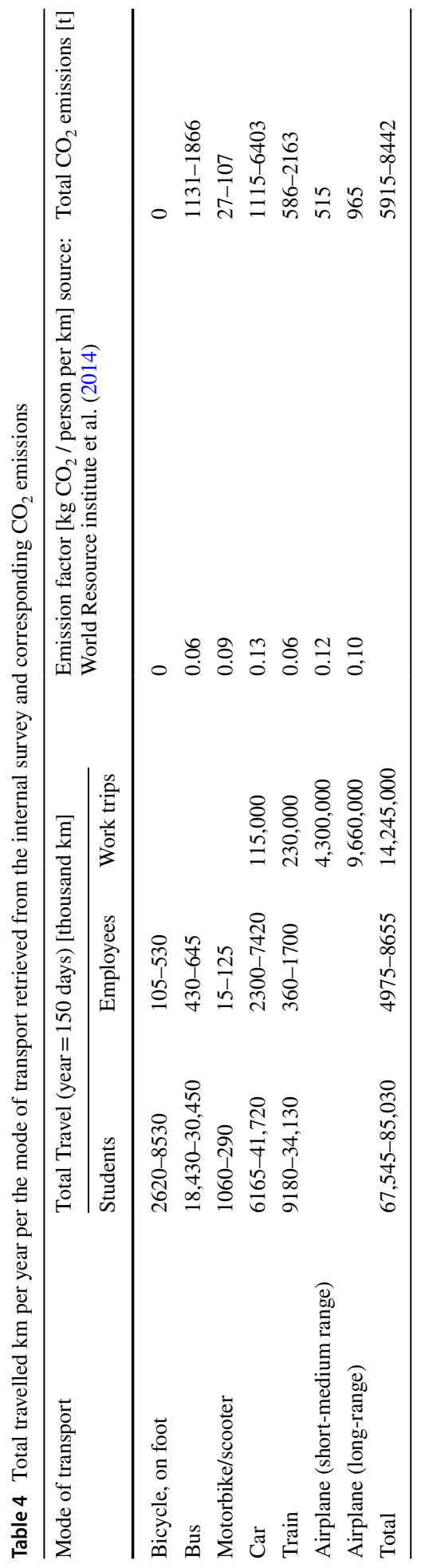


collection was carried out during October 2016 along with different types of spaces (laboratories, corridors, offices, etc.). Results of waste volume per bin were multiplied by the number of bins on the whole campus and volumes of waste were converted into $\mathrm{kg}$, using the specific factors as in Table 5. Data on collection frequency have been provided by the facility management office. These data are certainly not sufficient to return a realistic image of the waste produced within a year. However, they allowed preliminary considerations about the contribution that this aspect can have within the total EF.

Emissions of greenhouse gases linked to the waste recycling process referred to a study on the impact of waste treatment processes allocated by material type (Kirkeby et al., 2006; D. A. Turner et al., 2015). The forested area necessary for the absorption of these emissions is calculated using the procedure already reported for the other consumption categories.

\subsection{Food}

The services related to food encompassed the employee's canteen, the students' canteen and four coffee shops. To obtain the quantity of food consumed by the various services, interviews with key staff members were conducted, in the two central canteens (serving, daily, over 2,000 meals), the coffee shops at Mirafiori and Castello del Valentino. Food production is linked to three different types of land: forested area (necessary for the absorption of $\mathrm{CO}_{2}$ emissions related to the energy used for food processing); cropland and grazing land. The $\mathrm{CO}_{2}$ emissions related to the production of a specific food are then quantified by multiplying the consumption (in mass) of a given food by the associated embodied energy (Appendix-Table 8) and by the $\mathrm{CO}_{2}$ emission factor for the use of primary energy. The hectares of forested land are subsequently multiplied by the equivalence factor of $1.28 \mathrm{gha} / \mathrm{ha}$. The agricultural land has been quantified by dividing the annual consumption, expressed in $\mathrm{kg}$, of a given food by the average productivity of the agricultural land, expressed in $\mathrm{kg} / \mathrm{ha}$. The average productivity associated with cultivation derives from a survey regarding Italian agricultural production in 2011 (Sardone, 2012). The hectares of agricultural land are multiplied by the equivalence factor of agricultural land of $2.52 \mathrm{gha} /$ ha (Lin et al., 2016). When it was not possible to trace the primary product, for example for dairy products, the footprint intensity (the global productive hectares necessary to obtain $1 \mathrm{~kg}$ of a given good) was used (Appendix-Table 9). Hectares for the grazing land were obtained by multiplying the consumption of a product by the footprint intensity expressed in $\mathrm{gha} / \mathrm{kg}$. The area was then multiplied by the equivalence factor of the grazing land of 0.43 gha/ha (Table 6).

Table 5 Emissions of greenhouse gases linked to the waste management process

\begin{tabular}{llllll}
\hline Type of waste & $\begin{array}{l}\text { Volumes } \\
\left(\mathrm{m}^{3} / \text { year }\right)\end{array}$ & $\begin{array}{l}\text { Specific } \\
\text { weight }(\mathrm{kg} / \\
\left.\mathrm{m}^{3}\right)\end{array}$ & $\begin{array}{l}\text { Waste pro- } \\
\text { duction }(\mathrm{t})\end{array}$ & $\begin{array}{l}\mathrm{CO}_{2} \text { emission factor } \\
\left(\mathrm{kgCO}_{2} / \text { tonne }\right)\end{array}$ & $\mathrm{CO}_{2}$ emission (t) \\
\hline Paper & 998 & 200 & 212 & 559 & 118.3 \\
Plastic & 339 & 20 & 7 & 338 & 2.3 \\
Glass and cans & 187 & 120 & 22 & 468 & 10.5 \\
Undifferentiated & 3547 & 75 & 266 & 1910 & 508.2 \\
Organic & 11 & 100 & 1 & 200 & 0.3 \\
Total & & 507 & & 640 \\
\hline
\end{tabular}


Table $6 \mathrm{CO}_{2}$ emissions and land needed to support food consumption

\begin{tabular}{|c|c|c|c|c|c|c|}
\hline Type of food & $\begin{array}{l}\text { Yearly con- } \\
\text { sumption (t/ } \\
\text { year) }\end{array}$ & $\begin{array}{l}\mathrm{CO}_{2} \text { emis- } \\
\text { sions (kg } \\
\left.\mathrm{CO}_{2}\right)\end{array}$ & $\begin{array}{l}\text { Carbon } \\
\text { uptake land } \\
\text { (gha) }\end{array}$ & Cropland (gha) & $\begin{array}{l}\text { Graz- } \\
\text { ing land } \\
\text { (gha) }\end{array}$ & Total land (gha) \\
\hline $\begin{array}{l}\text { Cereals and } \\
\text { bread }\end{array}$ & 65.4 & 90.2 & 32.2 & 29.0 & - & 61.2 \\
\hline $\begin{array}{l}\text { Fruits and } \\
\text { vegetables }\end{array}$ & 163.3 & 127.4 & 45.4 & 22.1 & - & 67.5 \\
\hline Meat & 39.6 & 134.0 & 47.8 & 17.6 & 29.3 & 94.7 \\
\hline $\begin{array}{l}\text { Dairy products } \\
\text { and eggs }\end{array}$ & 35.7 & 25.2 & 9.0 & 67.6 & 39.3 & 115.9 \\
\hline Drinks & 73.6 & 67.5 & 24.1 & - & - & 24.1 \\
\hline $\begin{array}{l}\text { Other (sugar, } \\
\text { oil, etc.) }\end{array}$ & 19.5 & 18.3 & 6.5 & 25.1 & - & 31.6 \\
\hline Total & 397.1 & 462.6 & 165 & 161.4 & 68.6 & 395 \\
\hline
\end{tabular}

\section{Results}

The total PoliTO EF was obtained summing up the EF of the different consumption categories (Table 7) according to the methodology described in Sect. 2. Acknowledging the ambiguity of the EF indicators regarding the mobility impact, the analysis encompasses two extreme scenarios (one more "eco-friendly" and one less "eco-friendly") and a third intermediate situation that has been used for the final results being the most reliable.

Table 7 EFs of PoliTO activities related to the consumption categories.Source: (Genta et al., 2019)

\begin{tabular}{llrlr}
\hline Component & $\begin{array}{l}\text { Ecological foot- } \\
\text { print [gha] }\end{array}$ & \% of Total EF & $\begin{array}{l}\text { Carbon footprint } \\
\text { [tCO2] }\end{array}$ & \% of Total CF \\
\hline Energy & 2495 & 40.1 & 6997 & 40.4 \\
Electricity & 1810 & 29.1 & 5077 & 29.3 \\
Heating & 685 & 11.0 & 1920 & 11.1 \\
Water & 33 & 0.5 & 93 & 0.5 \\
Mobility & 3071 & 49.3 & 9144 & 52.7 \\
Commuting students & 2120 & 34.0 & 5946 & 34.3 \\
Commuting staff & 294 & 4.7 & 1354 & 7.8 \\
Work trips & 657 & 10.6 & 1844 & 10.6 \\
Use of land & 44 & 0.7 & & \\
Waste & 94 & 3.7 & 639 & 3.7 \\
Recycled waste & 47 & 0.8 & 131 & 0.8 \\
Unsorted waste & 181 & 2.9 & 508 & 2.9 \\
Food & 356 & 5.7 & 462 & 2.7 \\
Canteen & 286 & 4.6 & 382 & 2.2 \\
Bar & 70 & 1.1 & 80 & 0.5 \\
Total for all components & 6227 & 100.0 & 17,335 & 100.0 \\
EF/CF per person (students) & 0.19 & & 0.53 & \\
\hline
\end{tabular}


Given the uncertainty or incompleteness of some data sources, results must be intended to give an order of magnitude of the total EF breakdown that can serve as a basis for decision making and policy design processes. Moreover, some considerations can be made about the contribution of single categories and their results. The share of the different consumption categories is reported in Fig. 1 : mobility has the highest one, counting for $49.3 \%$ of the total, followed by energy (40.1\%); the share of water is $0.5 \%$, land use has $0.7 \%$, waste has $3.7 \%$ and food has $5.7 \%$.

The "most eco-friendly" and the "least eco-friendly" scenarios range between 2000 gha (of which 1700 due to students' commuting) and 3800 gha (3400 gha by students commuting). Work trips are based on real data from travel refunds and the major impacts, 550 gha out of a total of 650 gha, are associated with flights, while the remaining 100 gha refer to other means of transport (mainly private cars or trains).

As presented in the introduction, PoliTO has different campuses that contribute differently to the overall environmental impact of the University. The Engineering campus is the main headquarter site of PoliTO, where major teaching, research and administrative activities take place. Therefore, it accounts for $83 \%$ of the total environmental impact in terms of EF (5,186 gha), followed by Valentino Castle (10\% of the total EF) and Mirafiori and Lingotto (representing less than $10 \%$ of the global result).

\section{Discussion and Conclusions}

According to the results in par.3, the PoliTO campus would need an average of 6200 gha, or 0.19 hectares per student: half of the entire city of Turin. Compared to the university buildings total footmark (20 hectares), the PoliTO functioning requires an area that is 310 times larger than the actual one.

The normalized EF per student resulted, however, in line with other European universities with similar dimensions, campus structure and socio-economic context. Among recent studies, KHLeuven (Belgium) EF resulted in 0.35 gha per person (student and staff) (Lambrechts \& Van Liedekerke, 2014) with the major share of impact related to mobility activities. EFs of Valencia University (Spain) was 0.81 gha per student (TorregrosaLópez et al., 2011). However, the direct comparison of quantitative results is weak due to the lack of a common and shared framework of analysis. In fact, in recent years, HEIs measured their environmental impact by considering different methodologies, domains of analysis, reference units or boundaries of the system (Klein-Banai \& Theis, 2011; Ortegon \& Acosta, 2019; Townsend \& Barrett, 2015). It is interesting to highlight that the majority of consulted studies agree with EF evaluation of PoliTo in the definition of main areas of impact, identifying daily student commuting and energy consumption as main drivers of environmental impact. Concerning the objectives of the evaluation processes of $\mathrm{EF}$ or $\mathrm{CF}$ of an HEI they frequently aim at identifying hotspots of environmental impact, reporting on the sustainability performance of campuses, raising awareness among the internal community and guiding the design of transformational strategies (Lambert \& Cushing, 2017; Townsend \& Barrett, 2015).

Despite the EF methodology limits such as (i), the uncertainty in the different impact calculation methodologies (ii), the difficulty to find the right boundaries of the system (iii) and the scarce reliability of a normalized indicator for the overall performance (iv) (Goldfinger et al., 2014), this EF application certainly provided the first understanding 
of PoliTO environmental impact and became the starting point for future decision-making processes. An important side effect was related to the data-gathering phase which was used for internal assessment. This is extremely helpful for self-and inter-comparison of the efficacy of sustainability-related policy. Moreover, the data collection work created a network of expertise exchanges and resources, educational materials, people, events and languages in which equilibrium and conflicts coexisted and alternated along with all the calculation phase, yet producing a greater awareness of the opportunities and weaknesses at PoliTO in all the stakeholders involved.

This work was also a valid contribution to the Masterplan Team of PoliTo working on the strategic development of campuses and spaces. Through the spatialization of some strategies in the main engineering campus, the EF could be able to be reduced by $21 \%$ (Genta et al., 2019). The morphologic strategies impact the urban sprawl, decrease commuting distances, reduce $\mathrm{CO}_{2}$ emissions and energy consumptions (Cottafava et al., 2018; P. Lombardi et al., 2014). Actions are envisaged in the outdoor spaces of the campus because they have been identified as a platform where social interactions and informal learning take place, as well as places of maximum permeability, connectivity and accessibility.

Ecological footprint indicators, like sustainability indicators in general, synthesize and report on various complex areas, including social, environmental and economic aspects which strongly depends on the interlinks paying out in a specific context. However, an ecological footprint methodology and related indicators for campus sustainability are in general actionable in almost all campuses which will have to discuss about creating an agency and then practical steps to address factors contributing to a more local indicator attaining sustainability goals. Although some sustainability challenges addressed in one setting may overlap to some degree in another, there will also be distinct challenges (i.e. related to the energy consumption and the kind of renewable source to mitigate the impact available in that region) that can be transferred to another context if the evaluator takes care of few recommendation when elaborating the results, that should be: actionable, transferable and scalable, intergenerational (especially among the wide range of ages within a university administrative/students/ professors' staff), definable, relevant, important and measurable.

Because some sustainability goals may require long-term solutions, the ecological footprint approach would be applicable in the short-term but also intergenerational and usable in a long-term time frame, thus influencing the policy of future Italian Higher Education institutions inherently concerned about intergenerational impacts, thus differentiating ecological footprint indicators from many commonly used environmental indicators that reflect just the current state of the environment.

One approach that can be used to address decision and policymakers for these intergenerational dimensions is the use of "stock-and-flow indicators". Stock-and-flow indicators within the ecological footprint calculation may address the availability of a resource and the rate of depletion or growth; policy indicators are more applicable to assessing change over short periods of time (intragenerational), but stock-and-flow indicators will require multiagency cooperation, that can, however, complicate the quantification of an indicator and introduce additional uncertainty.

Therefore, the approach adopted in the case of PoliTO could be replicated in other HEIs or organizations as an effective methodology to support the preliminary phases of development of an internal strategy towards sustainable development and environmental impact reduction. The identification of major hotspots of environmental impacts can be the basis 
for the discussion and definition of sustainability policies. Additionally, the integration of different domains of sustainability of an HEI in a single picture can support the dialogue among sectors towards the definition of integrated strategies overcoming silos structure.

It is quite evident that even the best technical efforts will not produce a massive shift towards a more sustainable campus if not accompanied by a sociological, psychological and communicative strategy, linking the campus space with its actual community and the surrounding. It is of the utmost importance, of course, to consider social, economic and environmental aspects, besides the urban context, in achieving sustainable development (Sonetti et al., 2019). To this end, the proposed approach can be an effective communicative element to support the involvement of the PoliTO community to promote sustainable behaviours inside university premises. However, this study made evident the need for a sociological, psychological and communicative strategy alongside a quantitative data analysis, linking the campus strategy with the local community that represents a further development of this work.

In a broader context, the inquiry about the relevance of the EF indicator for actual policy design remains uncertain in the academic debate: are footprint accounts strategically pertinent to help a university achieve a holistic sustainable performance? That is still to be thoroughly assessed. For instance, Van den Bergh and Grazi (2014) has recently criticized the use of EF for university campus management because it is based on "phantom hectares". However, the opposite could be argued that a significant number of current evaluation approaches are not useful in supporting the management of sustainability. Moreover, adopting an EF, a decision-maker is forced to think about biocapacity deficiencies as a critical danger, not only for the local context but for the planetary boundaries. In particular, for an HEI, an EF assessment can act at the same time as a tool for structurinsg sustainable urban regeneration interventions and for making the impact of the environmental problems visible also at a wider international level.

In conclusion, given the role of universities in the future shaping of tomorrow's citizens, the awareness of the impacts related to campus life provided by an EF study as the one illustrated in this paper appears to be a crucial step towards a more just, environmentally friendly and human-centred society.

\section{Appendix}

See Tables 8 and 9.

Table 8 Embodied energy considered for the various types of assessed food

\begin{tabular}{|c|c|c|c|}
\hline Bread: $30 \mathrm{MJ} / \mathrm{kg}$ & $\begin{array}{l}\text { Vegetables: } 14.57 \mathrm{MJ} \\
\text { / kg }\end{array}$ & Eggs: $1.02 \mathrm{MJ} / \mathrm{kg}$ & $\begin{array}{l}\text { Processed meats: } 31.28 \mathrm{MJ} \\
\quad / \mathrm{kg}\end{array}$ \\
\hline Pasta / rice: $13 \mathrm{MJ} / \mathrm{kg}$ & Legumes: $20 \mathrm{MJ} / \mathrm{kg}$ & Poultry: $40 \mathrm{MJ} / \mathrm{kg}$ & Fish: $57.52 \mathrm{MJ} / \mathrm{kg}$ \\
\hline $\begin{array}{l}\text { Brioches / cakes: } 30 \mathrm{MJ} \\
\text { / kg }\end{array}$ & Cheese: 33.34 MJ / kg & Bovine: $49.18 \mathrm{MJ} / \mathrm{kg}$ & Bottled drinks: $15 \mathrm{MJ} / \mathrm{kg}$ \\
\hline Fruit: $6.97 \mathrm{MJ} / \mathrm{kg}$ & Milk / yogurt: $7 \mathrm{MJ} / \mathrm{kg}$ & Pig: $31 \mathrm{MJ} / \mathrm{kg}$ & Coffee: $14.3 \mathrm{MJ} / \mathrm{kg}$ \\
\hline Wine / beer: $15 \mathrm{MJ} / \mathrm{kg}$ & Sugar: 15 MJ / kg & Oil: 15 MJ / kg & \\
\hline
\end{tabular}


Table 9 Footprint intensity for agricultural land for the various type of assessed food

\begin{tabular}{ll}
\hline Cereal land: $5,688 \mathrm{~kg} / \mathrm{ha}$ & Cheese: $23.2 \mathrm{~m}^{2} / \mathrm{kg}$ \\
Fruit: $15,183 \mathrm{~kg} / \mathrm{ha}$ & Milk and yoghurt: $2.3 \mathrm{~m}^{2} / \mathrm{kg}$ \\
Vegetable in full air: $19,577 \mathrm{~kg} / \mathrm{ha}$ & Eggs: $20.8 \mathrm{~m}^{2} / \mathrm{kg}$ \\
Olive tree: $2,985 \mathrm{~kg} / \mathrm{ha}$ & Coffee: $40.1 \mathrm{~m}^{2} / \mathrm{kg}$ \\
grape: $9,635 \mathrm{~kg} / \mathrm{ha}$ & \\
\hline
\end{tabular}

Funding Open access funding provided by Politecnico di Torino within the CRUI-CARE Agreement.

\section{Declarations}

Conflicts of interest The authors declare no conflict of interest.

Open Access This article is licensed under a Creative Commons Attribution 4.0 International License, which permits use, sharing, adaptation, distribution and reproduction in any medium or format, as long as you give appropriate credit to the original author(s) and the source, provide a link to the Creative Commons licence, and indicate if changes were made. The images or other third party material in this article are included in the article's Creative Commons licence, unless indicated otherwise in a credit line to the material. If material is not included in the article's Creative Commons licence and your intended use is not permitted by statutory regulation or exceeds the permitted use, you will need to obtain permission directly from the copyright holder. To view a copy of this licence, visit http://creativecommons.org/licenses/by/4.0/.

\section{References}

Agdas, D., Srinivasan, R. S., Frost, K., \& Masters, F. J. (2015). Energy use assessment of educational buildings: Toward a campus-wide sustainable energy policy. Sustainable Cities and Society, 17, 15-21. https://doi.org/10.1016/j.scs.2015.03.001

Baabou, W., Grunewald, N., Ouellet-Plamondon, C., Gressot, M., \& Galli, A. (2017). The Ecological Footprint of Mediterranean cities: Awareness creation and policy implications. Environmental Science and Policy, 69, 94-104. https://doi.org/10.1016/j.envsci.2016.12.013

Baboulet, O., \& Lenzen, M. (2010). Evaluating the environmental performance of a university. Journal of Cleaner Production, 18(12), 1134-1141. https://doi.org/10.1016/j.jclepro.2010.04.006

Baranzelli, I., Siragusa, C., \& Aurambout, J. P. (2019). The future of cities. Opportunieties, challenges and the way forward. Luxemburg: Publications Office. https://doi.org/10.2760/375209

Borucke, M., Moore, D., Cranston, G., Gracey, K., Iha, K., Larson, J., et al. (2013). Accounting for demand and supply of the biosphere's regenerative capacity: The National Footprint Accounts' underlying methodology and framework. Ecological Indicators, 24, 518-533. https://doi.org/10.1016/j.ecolind. 2012.08.005

Brandon, P. S., \& Lombardi, P. (2011). Evaluating sustainable development in the built environment. Blackwell Publishing Ltd.

Caeiro, S., Filho, W. L., Jabbour, C., \& Azeiteiro, U. M. (Eds.). (2013). Sustainability assessment tools in higher education institutions. Cham: Springer International Publishing. https://doi.org/10.1007/ 978-3-319-02375-5

Castellani, V., Beylot, A., \& Sala, S. (2019). Environmental impacts of household consumption in Europe: Comparing process-based LCA and environmentally extended input-output analysis. Journal of Cleaner Production, 240, 117966. https://doi.org/10.1016/j.jclepro.2019.117966

Chambers, N., Simmons, C., \& Wackernagel, M. (2014). Sharing nature's interest: Ecological footprints as an indicator of sustainability. Routledge.

Chung, M. H., \& Rhee, E. K. (2014). Potential opportunities for energy conservation in existing buildings on university campus: A field survey in Korea. Energy and Buildings, 78, 176-182. https://doi.org/10. 1016/j.enbuild.2014.04.018

Colglazier, W. (2015). Sustainable development agenda: 2030. Science, 349(6252), 1048-1050.

Collins, A., Galli, A., Patrizi, N., \& Pulselli, F. M. (2018). Learning and teaching sustainability: The contribution of Ecological Footprint calculators. Journal of Cleaner Production, 174, 1000-1010. https:// doi.org/10.1016/j.jclepro.2017.11.024 
Conway, T. M., Dalton, C., Loo, J., \& Benakoun, L. (2008a). Developing ecological footprint scenarios on university campuses: A case study of the University of Toronto at Mississauga. International Journal of Sustainability in Higher Education, 9(1), 4-20. https://doi.org/10.1108/14676370810842157

Conway, T. M., Dalton, C., Loo, J., Benakoun, L., Conway, T. M., Dalton, C., \& Loo, J. (2008b). Developing Ecological Footprint Scenarios on University Campuses A Case Study of the University of Toronto at Mississauga. https://doi.org/10.1108/14676370810842157

Cortese, A. D. (2003). The critical role of higher education in creating a sustainable future. Planning for Higher Education, 31(3), 15-22.

Cottafava, D., Sonetti, G., Gambino, P., \& Tartaglino, A. (2018). Explorative Multidimensional Analysis for Energy Efficiency: DataViz versus Clustering Algorithms. Energies, 11(5), 1312.

Deakin, M., Curwell, S., \& Lombardi, P. (2002). Sustainable urban development: The framework and directory of assessment methods. The International Journal of Life Cycle Assessment, 6(6), 373-383.

Disterheft, A., Caeiro, S., Azeiteiro, U. M., \& Filho, W. L. (2014). Sustainable universities - a study of critical success factors for participatory approaches. Journal of Cleaner Production, 106, 11-21. https:// doi.org/10.1016/j.jclepro.2014.01.030

Disterheft, A., Caeiro, S. S., Leal Filho, W., \& Azeiteiro, U. M. (2016). The INDICARE-model-measuring and caring about participation in higher education's sustainability assessment. Ecological Indicators, 63, 172-186.

Escobedo, A., Briceño, S., Juárez, H., Castillo, D., Imaz, M., \& Sheinbaum, C. (2014). Energy consumption and GHG emission scenarios of a university campus in Mexico. Energy for Sustainable Development, 18(1), 49-57. https://doi.org/10.1016/j.esd.2013.10.005

Ferrer-Balas, D., Buckland, H., \& de Mingo, M. (2009). Explorations on the University's role in society for sustainable development through a systems transition approach. Case-study of the Technical University of Catalonia (UPC). Journal of Cleaner Production, 17(12), 1075-1085.

Galli, A., Giampietro, M., Goldfinger, S., Lazarus, E., Lin, D., Saltelli, A., et al. (2016). Questioning the Ecological Footprint. Ecological Indicators, 69, 224-232. https://doi.org/10.1016/j.ecolind.2016. 04.014

Genta, C., Favaro, S., Sonetti, G., Barioglio, C., \& Lombardi, P. (2019). Envisioning green solutions for reducing the ecological footprint of a university campus. International Journal of Sustainability in Higher Education. https://doi.org/10.1108/IJSHE-01-2019-0039

Giampietro, M., \& Saltelli, A. (2014). Footworking in circles: Reply to Goldfinger et al. (2014) "footprint Facts and Fallacies: A Response to Giampietro and Saltelli (2014) Footprints to nowhere." Ecological Indicators, 46, 260-263. https://doi.org/10.1016/j.ecolind.2014.06.019

Global Footprint Network. (2016). National Footprint and Biocapacity Accounts, 2016 edition.

Goldfinger, S., Wackernagel, M., Galli, A., Lazarus, E., \& Lin, D. (2014). Footprint facts and fallacies: A response to Giampietro and Saltelli (2014) "Footprints to Nowhere." Ecological Indicators, 46, 622-632. https://doi.org/10.1016/j.ecolind.2014.04.025

Gottlieb, D., Vigoda-Gadot, E., Haim, A., \& Kissinger, M. (2012). The ecological footprint as an educational tool for sustainability: A case study analysis in an Israeli public high school. International Journal of Educational Development, 32(1), 193-200.

IPCC. (2018). Global warming of $1.5^{\circ} \mathrm{C}$ An IPCC Special Report on the impacts of global warming of $1.5^{\circ} \mathrm{C}$ above pre-industrial levels and related global greenhouse gas emission pathways, in the context of strengthening the global response to the threat of climate change. https://doi.org/10.1017/ CBO9781107415324

ISPRA. (2015). Fattori di emissione atmosferica di CO2 e sviluppo delle fonti rinnovabili nel settore elettrico.

Ivanova, D., Vita, G., Steen-Olsen, K., Stadler, K., Melo, P. C., Wood, R., \& Hertwich, E. G. (2017). Mapping the carbon footprint of EU regions. Environmental Research Letters, 12(5), 54013.

Kirkeby, J. T., Birgisdottir, H., Hansen, T. L., Christensen, T. H., Bhander, G. S., \& Hauschild, M. (2006). Environmental assessment of solid waste systems and technologies: EASEWASTE. Waste Management \& Research, 24(1), 3-15.

Kitzes, J., Galli, A., Bagliani, M., Barrett, J., Dige, G., Ede, S., et al. (2009). A research agenda for improving national Ecological Footprint accounts. Ecological Economics, 68(7), 1991-2007. https://doi.org/10.1016/j.ecolecon.2008.06.022

Klein-Banai, C., \& Theis, T. L. (2011). An urban university's ecological footprint and the effect of climate change. Ecological Indicators, 11(3), 857-860. https://doi.org/10.1016/j.ecolind.2010.11.002

Klein-Banai, C., \& Theis, T. L. (2013). Quantitative analysis of factors affecting greenhouse gas emissions at institutions of higher education. Journal of Cleaner Production, 48, 29-38. 
Lambert, M., \& Cushing, K. K. (2017). How low can you go?: Understanding ecological footprint reduction in university students, faculty and staff. International Journal of Sustainability in Higher Education, 18(7), 1142-1156. https://doi.org/10.1108/IJSHE-08-2015-0145

Lambrechts, W., \& Van Liedekerke, L. (2014). Using ecological footprint analysis in higher education: Campus operations, policy development and educational purposes. Ecological Indicators, 45, 402406. https://doi.org/10.1016/j.ecolind.2014.04.043

Larsen, H. N., Pettersen, J., Solli, C., \& Hertwich, E. G. (2013). Investigating the Carbon Footprint of a University - The case of NTNU. Journal of Cleaner Production, 48, 39-47.

Leal Filho, W., Azeiteiro, U., Alves, F., Pace, P., Mifsud, M., Brandli, L., et al. (2018). Reinvigorating the sustainable development research agenda: The role of the sustainable development goals (SDG). International Journal of Sustainable Development and World Ecology, 25(2), 131-142. https://doi.org/10.1080/13504509.2017.1342103

Li, G. J., Wang, Q., Gu, X. W., Liu, J. X., Ding, Y., \& Liang, G. Y. (2008). Application of the componential method for ecological footprint calculation of a Chinese university campus. Ecological Indicators, 8(1), 75-78. https://doi.org/10.1016/j.ecolind.2007.01.007

Lin, D., Hanscom, L., Martindill, J., Borucke, M., Cohen, L., Galli, A., et al. (2016). Working Guidebook to the National Footprint Accounts: 2016 Edition. Global Footprint Network report. http://www.footp rintnetwork.org/images/article_uploads/NFA 2014 Guidebook 7-14-14.pdf

Lombardi, P., Acquaviva, A., Macii, E., Osello, A., Patti, E., \& Sonetti, G. (2014). Web and cloud management for building energy reduction: Toward a smart district information modelling. Open Source Technology: Concepts, Methodologies, Tools and Applications (Vol. 4-4). https://doi.org/10.4018/9781-4666-7230-7.ch079

Lombardi, P., \& Sonetti, G. (2017). News from the front of sustainable university campuses. Roma: Edizioni Nuova Cultura.

Lozano, R. (2010). Diffusion of sustainable development in universities' curricula: An empirical example from Cardiff University. Journal of Cleaner Production, 18(7), 637-644. https://doi.org/10.1016/j. jclepro.2009.07.005

Lozano, R., Carpenter, A., \& Huisingh, D. (2014). A review of 'theories of the firm' and their contributions to Corporate Sustainability. Journal of Cleaner Production, 106, 430-442. https://doi.org/10.1016/j. jclepro.2014.05.007

Mulder, K. F., Ferrer, D., Segalas Coral, J., Kordas, O., Nikiforovich, E., \& Pereverza, K. (2015). Motivating students and lecturers for education in sustainable development. International Journal of Sustainability in Higher Education, 16(3), 385-401.

Munier, N. (2011). Methodology to select a set of urban sustainability indicators to measure the state of the city and performance assessment. Ecological Indicators, 11(5), 1020-1026.

Nathaniel, S. P. (2020a). Ecological footprint, energy use, trade and urbanization linkage in Indonesia. GeoJournal, 1-14.

Nathaniel, S. P. (2020b). Biocapacity, human capital and ecological footprint in G7 countries: The moderating role of urbanization and necessary lessons for emerging economies. Energy, Ecology and Environment, 1-16.

Nunes, L. M., Catarino, A., Ribau Teixeira, M., \& Cuesta, E. M. (2013). Framework for the inter-comparison of ecological footprint of universities. Ecological Indicators, 32, 276-284. https://doi.org/10. 1016/j.ecolind.2013.04.007

Omojolaibi, J. A., \& Nathaniel, S. P. (2020). Assessing the potency of environmental regulation in maintaining environmental sustainability in MENA countries: An advanced panel data estimation. Journal of Public Affairs, e2526.

Ortegon, K., \& Acosta, P. (2019). Ecological footprint: A tool for environmental management in educational institutions. International Journal of Sustainability in Higher Education, 20(4), 675-690. https://doi. org/10.1108/IJSHE-09-2018-0156

Ozawa-Meida, L., Brockway, P., Letten, K., Davies, J., \& Fleming, P. (2013). Measuring carbon performance in a UK University through a consumption-based carbon footprint: De Montfort University case study. Journal of Cleaner Production, 56, 185-198.

Ramos, T. B., Caeiro, S., van Hoof, B., Lozano, R., Huisingh, D., \& Ceulemans, K. (2015). Experiences from the Implementation of Sustainable Development in Higher Education Institutions: Environmental Management for Sustainable Universities. Journal of Cleaner Production, 106, 3-10. https://doi.org/ 10.1016/j.jclepro.2015.05.110

Rees, W., \& Wackernagel, M. (1996). Urban ecological footprints: Why cities cannot be sustainable-and why they are a key to sustainability. Environmental Impact Assessment Review, 16(4-6), 223-248.

Romanowska, A., Okraszewska, R., \& Jamroz, K. (2019). A study of transport behaviour of academic communities. Sustainability (Switzerland), 11(13). https://doi.org/10.3390/su11133519 
Sala, S., \& Castellani, V. (2019). The consumer footprint: Monitoring sustainable development goal 12 with process-based life cycle assessment. Journal of Cleaner Production, 240, 118050. https://doi.org/10. 1016/j.jclepro.2019.118050

Sardone, R. (2012). Dieci anni di agricoltura italiana: le principali evidenze dell'Annuario Inea. AgriRegioniEuropa.

Schaltegger, S., Bennett, M., \& Burritt, R. (2006). Sustainability accounting and reporting (Vol. 21). Springer Science \& Business Media.

Schaltegger, S., \& Wagner, M. (2006). Integrative management of sustainability performance, measurement and reporting. International Journal of Accounting, Auditing and Performance Evaluation, 3(1), 1-19.

Schuetze, T., \& Chelleri, L. (2015). Urban Sustainability Versus Green-Washing-Fallacy and Reality of Urban Regeneration in Downtown Seoul. Sustainability, 8(1), 33.

Shriberg, M. (2002). Institutional assessment tools for sustainability in higher education: Strengths, weaknesses and implications for practice and theory. International Journal of Sustainability in Higher Education, 3(3), 254-270. https://doi.org/10.1108/14676370210434714

Soltani, A., Allan, A., Nguyen, H. A., \& Berry, S. (2019). Students' commuting pattern from the viewpoint of environmentalism: Comparing Australia with China. International Journal of Sustainability in Higher Education, 20(1), 91-114. https://doi.org/10.1108/IJSHE-08-2018-0146

Sonetti, G., Barioglio, C., \& Campobenedetto, D. (2020). Education for Sustainability in Practice: A Review of Current Strategies within Italian Universities. Sustainability, 12(13), 5246. https://doi. org/10.3390/su12135246

Sonetti, G., Brown, M., \& Naboni, E. (2019). About the Triggering of UN Sustainable Development Goals and Regenerative Sustainability in Higher Education. Sustainability, 11(1), 254.

Sonetti, G., Lombardi, P., \& Chelleri, L. (2016). True Green and Sustainable University Campuses? Sustainability. Multidisciplinary Digital Publishing Institute. https://doi.org/10.3390/su8010083

Steffen, W., Broadgate, W., Deutsch, L., Gaffney, O., \& Ludwig, C. (2015). The trajectory of the anthropocene: The great acceleration. Anthropocene Review. https://doi.org/10.1177/2053019614564785

Steffen, W., Persson, A., Deutsch, L., Zalasiewicz, J., Williams, M., Richardson, K., et al. (2011). The Anthropocene : From Global Change to Planetary Stewardship. Royal Swedish Academy of Sciences. https://doi.org/10.1007/s13280-011-0185-X

Tejedor, G., Rosas-Casals, M., \& Segalas, J. (2019). Patterns and trends in engineering education in sustainability: A vision from relevant journals in the field. International Journal of Sustainability in Higher Education, 20(2), 360-377.

Thurston, M., \& Eckelman, M. J. (2012). Assessing Greenhouse Gas Emissions from University Purchases. https://doi.org/10.1108/14676371111148018

Torregrosa-López, J. I., Bellver Navarro, C. G., \& Lo Iacono-Ferrerira, V. G. (2011). Experiences in the use of Ecological Footprint as a sustainability indicator. Cuadernos de Biodiversidad, 37, 9-18. https://doi.org/10.14198/cdbio.2011.37.02

Townsend, J., \& Barrett, J. (2015). Exploring the applications of carbon footprinting towards sustainability at a UK university: Reporting and decision making. Journal of Cleaner Production, 107, 164-176.

Turner, D. A., Williams, I. D., \& Kemp, S. (2015). Greenhouse gas emission factors for recycling of source-segregated waste materials. Resources, Conservation and Recycling, 105, 186-197. https:// doi.org/10.1016/j.resconrec.2015.10.026

Turner, K., Lenzen, M., Wiedmann, T., \& Barrett, J. (2007). Examining the global environmental impact of regional consumption activities-Part 1: A technical note on combining input-output and ecological footprint analysis. Ecological Economics, 62(1), 37-44.

Udemba, E. N. (2020a). Ecological implication of offshored economic activities in Turkey: Foreign direct investment perspective. Environmental Science and Pollution Research, 27(30), 3801538028. https://doi.org/10.1007/s11356-020-09629-9

Udemba, E. N. (2020b). A sustainable study of economic growth and development amidst ecological footprint: New insight from Nigerian Perspective. Science of the Total Environment, 732(May), 139270. https://doi.org/10.1016/j.scitotenv.2020.139270

Udemba, E. N. (2020c). Mediation of foreign direct investment and agriculture towards ecological footprint: A shift from single perspective to a more inclusive perspective for India. Environmental Science and Pollution Research, 27(21), 26817-26834. https://doi.org/10.1007/s11356-020-09024-4

UN. (2015). Transforminng our world: The 2030 Agenda for Sustainable Development (Vol. 16301). https://doi.org/10.1007/s13398-014-0173-7.2

van den Bergh, J. C. J. M., \& Grazi, F. (2014). Ecological Footprint Policy? Land Use as an Environmental Indicator. Journal of Industrial Ecology, 18(1), 10-19. https://doi.org/10.1111/jiec.12045 
Vanham, D., Leip, A., Galli, A., Kastner, T., Bruckner, M., Uwizeye, A., et al. (2019). Environmental footprint family to address local to planetary sustainability and deliver on the SDGs. Science of the Total Environment, 693(June). https://doi.org/10.1016/j.scitotenv.2019.133642

Velazquez, L., Munguia, N., Platt, A., \& Taddei, J. (2006). Sustainable university: What can be the matter? Journal of Cleaner Production, 14(9-11), 810-819. https://doi.org/10.1016/j.jclepro.2005.12.008

Venetoulis, J. (2006). Assessing the ecological impact of a university. The ecological footprint for the University of Redlands.

Wackernagel, M., \& Rees, W. (1997). Our ecological footprint: Reducing human impact on the earth. New Society publisher.

Weidmann, T., \& Minx, J. (2007). A definition of "Carbon footprint." ISA UK research. http://www. censa.org.uk/docs/ISA-UK_Report_07-01_carbon_footprint.pdf

Wiedmann, T., \& Barrett, J. (2010). A review of the ecological footprint indicator-perceptions and methods. Sustainability, 2(6), 1645-1693. https://doi.org/10.3390/su2061645

Wiedmann, T. O., Lenzen, M., \& Barrett, J. R. (2009). Companies on the scale: Comparing and benchmarking the sustainability performance of businesses. Journal of Industrial Ecology, 13(3), 361-383.

Wood, R., Lenzen, M., Wood, R., \& Lenzen, M. (2010). An Application of a Modified Ecological Footprint Method and Structural Path Analysis in a Comparative Institutional Study An Application of a Modified Ecological Footprint Method and Structural Path Analysis in a Comparative Institutional Study, 9839. https://doi.org/10.1080/13549830306670

World Resource institute, Cities Climate Leadership group, \& Local Governments for sustainability. (2014). Global Protocol for Community-Scale Greenhouse Gas Emission Inventories: An Accounting and Reporting Standard for Cities, 1-176.

Publisher's Note Springer Nature remains neutral with regard to jurisdictional claims in published maps and institutional affiliations. 